\title{
Servant Teaching: An exploration of teacher servant leadership on student outcomes
}

\author{
Aaron Noland ${ }^{1}$ and Keith Richards ${ }^{2}$
}

\begin{abstract}
Servant leadership is an approach to leadership that embraces the opportunity for the leaders to embrace service to their followers. This approach to leadership puts the goals, needs, and development of "followers" ahead of those of the leader. Applying servant leadership to classroom contexts serves as an opportunity to improve education by positively impacting student learning, development, and deepening the student-centeredness of instruction. This paper examines the veracity of a servant approach to teaching by exploring its impacts on student learning, engagement, and motivation. The results of this study provide evidence that servant teaching is positively associated with student engagement and indicators of learning.
\end{abstract}

Keywords: Servant leadership, student learning, student engagement, student motivation

Instructional communication researchers have long since recognized the teacher as a leader in the classroom (Chory \& McCroskey, 1999; Richmond \& McCroskey, 1992), but more recently, the focus has turned to the relationship between certain teacher leadership behaviors and student outcomes such as learning, motivation, and satisfaction (Bolkan \& Goodboy, 2010; Bolkan, Goodby, \& Griffin, 2011; Noland \& Richards, 2014; Pounder, 2003, 2006;).

In combination with studying the relationship between teacher leadership and student outcomes, a trend of applying specific leadership theories to teacher leadership has emerged (Bolkan, Goodboy, \& Griffin, 2011; Horan, Chory, Carton, Miller, \& Raposo, 2013; Pounder, 2003; 2008). Pounder (2003) first applied transformational leadership to the classroom and has subsequently found extensive positive student outcomes associated with teacher transformational leadership. Some of these findings include improved critical thinking and the ability to generate novel approaches to problem solving (Pounder, 2003; 2008). A majority of this research has focused on teacher transformational leadership, but another appropriate model for the instructorstudent relationship is servant leadership.

Robert Greenleaf’s original work on servant leadership, “The Servant as Leader,” defined servant leadership as authentically concerned with serving followers (Greenleaf, 1977). Though an innovative approach to leadership, Greenleaf did not provide empirical validation of this approach and offered only prescriptions of what servant leaders should do without offering empirically based descriptions (van Dierendonck, 2011). The result has been an inconsistent set of dimensions based on Greenleaf's writing about servant leadership. To concretize the theory of servant leadership the current study will use Liden et al.’s (2008) seven core dimensions of servant

\footnotetext{
${ }^{1}$ Aaron Noland is a Lecturer at James Madison University 54 Bluestone Dr. Harrisonburg, VA 22807 nolandax@jmu.edu

${ }^{2}$ Dr. Keith Richards is an Assistant Professor at East Carolina University 116 Joyner East Greenville, NC 27858 richardsk@ecu.edu
} 
leadership and apply them to the classroom. This theoretical approach offers both a plurality of previous theorizing about servant leadership (Barbuto \& Wheeler, 2006; Greenleaf, 1977, 1998; Spears, 1998) and an empirically based operationalization of these seven dimensions. Servant leadership is altruistic leadership done in pursuit of follower development independent of larger self-serving goals (Greenleaf, 1977, 1998; Smith, Montagno, \& Kuzmenko, 2004; Stone, Russell, \& Patterson, 2004).

The purpose of this paper is to explore the relationship between teacher servant leadership behaviors and student outcomes. The project is specifically looking to determine if servant teaching behaviors are positively related to student learning, motivation, and engagement. Applying this model of leadership to an instructional context may provide teachers with clear behaviors they can enact to positively impact student learning, motivation, and engagement.

\section{Literature Review}

\section{Servant Teaching}

Servant leadership's emphasis on follower development and service as primary goals make it a valuable approach to teacher leadership. The central tenet of servant leadership is of primary importance: "the servant-leader (teacher) is servant first ... (they must) want to serve, to serve first” (Greenleaf, 1977, para. 1 \& 2). The integrity of this central tenet must be applied to the teacher as servant environment. The servant teacher is focused on education as relational, empowering, and liberating instead of on teaching as a one-way, top - down, authoritarian enterprise (Hays, 2008).

Distilling the key attributes or dimensions of servant teaching is important to further understand servant teaching. First, emotional healing is expressing a concern for student wellbeing and completeness and support during times of struggle. Second, creating value for the community means the teacher recognizes the interdependence of the community and student and works to inspire students to benefit under-privileged communities. Next, empowering students, emphasizes validating the intrinsic value of the student and helping them generate personal power to succeed. Fourth, helping students grow and succeed, suggests that teachers provide opportunities for students to engage a personal challenge and develop as a result. Fifth, servant teachers put students first, emphasizing student development above all other goals and elevating student welfare above self. This can manifest in many ways some of which may be altering pedagogical approaches and assessment methods in response to student needs. Next, servant teachers demonstrate conceptual skills by balancing classroom management, instruction, and vision tasks while assisting students in achieving success. Finally, behaving ethically, embodying honesty and integrity in interactions and serving as a role model for students is a key element to servant teaching. Transparency and follow-through help to build trust and honesty establishes ethical standards for the classroom and beyond (Drury, 2005; Greenleaf, 1977, 1998; Hays, 2008; Hunter et al., 2013; Liden et al., 2008; Patterson, 2003; Smith et al., 2004; Stone, Russell, \& Patterson, 2004; van Dierendonck, 2011).

Servant leadership's potential transferability to teacher leadership is evident in the existing research linking servant leadership to high quality leader-member exchanges, positive attitudes, high levels of commitment, and performance (van Dierendonck, 2011). These outcomes manifest in a classroom setting in similar, albeit different, ways. A positive attitude about work is analogous to affective learning, commitment should impact motivation, and performance is analogous to 
cognitive learning (Noland \& Richards, 2014). However, relative little literature investigates the impact of servant teaching on student outcomes. Bowman (2005) and Drury (2005) both argue for more scholarship to explore the relationships between servant teaching and student outcomes, namely student learning.

\section{Student Motivation}

Student motivation is a powerful mediating variable between instructor behaviors and student outcomes (Jaasma \& Koper, 1999) and thus provides an important variable of study in instructional leadership. If teacher leaders can positively impact motivation then they are likely to be able to indirectly impact other student outcomes such as learning, but motivation can also function as an outcome variable (Frymier \& Shulman, 1995; Richmond, 1990).

Motivation has been conceptualized as a contextual state or more stable trait variable (Frymier \& Shulman, 1995). Student state motivation is contingent upon other variables, such as class topic, and varies across different situations; however, trait motivation is a stable attribute referring to a student's motivation to perform a specific task (Bolkan \& Goodboy, 2011; Frymier \& Shulman, 1995). Teachers are well positioned to impact student state motivation through activity levels in the classroom, inspiration, leadership behaviors, and passion (Bolkan, Goodboy \& Griffin, 2011; Morton, Keith, \& Beauchamp, 2010). Teacher behaviors such as immediacy, clarity, caring, confirmation, and humor all positively predict student motivation (Comadena, Hunt \& Simonds, 2007; Frymier, 1993; Myers, et al., 2014). Richmond (1990) argued that in class interactions are the best way to improve motivation and deepen student learning experiences as teachers have the ability to increase student state and trait motivation by challenging students and affirming their growth.

The relationship between teacher transformational leadership and student motivation has been demonstrated in studies by Morton, Keith, and Beauchamp (2010) and Pounder (2009). Individualized consideration, an element of transformational leadership focused on treating followers as individuals, significantly predicts student motivation (Noland \& Richards, 2014) and is highly correlated with servant leadership (Hunter et al., 2013). Servant teaching focuses first on the student, providing challenge while affirming and encouraging student development above other goals (Greenleaf, 1998; Hays, 2008). Hays (2008) found students with servant teachers were more empowered, confident, and invested. These interconnected relationships lead to the conclusion that servant teaching should positively impact student motivation.

RQ1: Are servant teaching and student motivation correlated?

\section{Student Learning}

According to Bloom (1956), student learning can be divided into three different types of learning: cognitive, affective, and/or behavioral. For the purposes of this paper affective and cognitive learning are of primary concern. Affective learning is the attitude (positive or negative valence) toward learning in a particular context; cognitive learning is concerned with how students understand and retain information (Bloom, 1956).

Cognitive learning, receiving, retaining, and applying new information, is an outcome based approach to learning (Messman \& Jones-Corley, 2001). It is the type of learning that is often assessed on exams, writing assignments, and presentations. According to Rodriguez, Plax, and Kearney (1996) cognitive learning is the function of a variety of other "inputs" such as student 
motivation, teacher immediacy behaviors, and affective learning. This model, confirmed in their study, provides a clear path for positively influencing student cognitive learning. Cognitive learning is influenced by a host of teacher behaviors such as clarity, caring, confirmation, and affective learning (Goodboy \& Myers, 2008; Frymier, 1993; Sidelinger \& McCroskey, 1997; Teven \& McCroskey, 1997). Servant teachers are uniquely positioned to leverage conceptual skills to increase clarity and simultaneously leverage empowerment, healing, and putting students first to increase caring and confirmation.

Affective learning, the attitudinal aspect of learning, varies with task, instructor, and course (Bolkan \& Goodboy, 2011; Rodriguez, Plax, \& Kearney, 1996; Sidelinger \& McCroskey, 1997). Increasing student affective learning is a moderator to increasing student cognitive learning and engagement. The more positive an evaluation of course, content, or instructor the more likely students are to show gains in cognitive learning (Rodriguez, Plax, \& Kearney, 1996). Teacher behaviors are particularly impactful in increasing student affective learning. Teacher behaviors such as immediacy, organization, engaging delivery, enthusiastic seeking of goals, and positivity uniquely impact student attitudes toward their instructor and course content (Kark, Shamir, \& Chen, 2003; Pounder, 2006; Sorensen, 1989). Transformational leadership has shown a significant positive relationship to affective learning as students with transformational teachers report high levels of affective learning (Bogler, Caspi, \& Roccas, 2013; Noland \& Richards, 2014; Pounder, 2009).

Servant teaching should be positively related to student affective learning as students feel challenged, supported, are given the affirmation, and are cared for personally (Greenleaf, 1977; Hunter et al., 2013; Liden et al., 2008). The empowering nature of servant leadership along with healing and servitude should positively impact the affective dimensions of learning as students feel a sense of pride to be associated with their teacher, are encouraged to take an active role in the learning process, and engage with course content (Bowman, 2005; Drury, 2005; Hays, 2008). On the other hand, the trailblazing attributes wherein servant teachers remove barriers to success, and the use of conceptual skills to increase teacher clarity and organization should increase student cognitive learning (Greenleaf, 2003; Hays, 2008; Myers, et al., 2014;). As a result, the following research question is offered:

RQ2: Are servant teaching and student learning correlated?

\section{Student Engagement}

Engagement in the classroom is made up of a variety of factors (Appleton, Christenson, Kim, \& Reschly, 2006; Jimerson, Campos, \& Grief, 2003; Krause \& Coates, 2008). Some characteristics of an engaged student are that they are doing the work, following the class rules, being motivated, and participating both in and outside of class (Zyngier, 2008). One important aspect in creating an engaging classroom environment is that both the student and the teacher play a role in the process (Krause \& Coates, 2008; Linville, 2014). Engagement helps to predict high quality learning and is positively related to performance (Carini, Kuh, \& Klein, 2006; Fredricks, Blumenfeld, \& Paris, 2004; Klem \& Connel, 2004; Krause \& Coates, 2008; Skinner, Furrer, Marchand, \& Kindermann, 2008).

Mazer (2012b, 2013a, 2013b,) found that students who scored highest on emotional and cognitive interest were the most engaged in the classroom and were more likely to think deeply about the material. Engaged students are more likely to pay attention, be interested, and embrace challenges compared to those students who are not engaged (Klem \& Connel, 2004). In contrast, 
disengaged students are passive and let external forces influence their involvement in learning (Reeve, et al., 2004). Students who are persistent in their effort to embrace challenges will often find new challenges to be more enjoyable (Skinner, et al., 2008). If the student is prepared the teacher needs to draw out these characteristics by creating course content that is interesting and applicable to the students (Linville, 2014).

In order to increase the likelihood of student engagement, teachers need to pay attention to the individual differences in their students (Linville, 2014). Teachers who have clear expectations, create a caring environment with positive emotions, and support their students often have students who report being engaged (Klem \& Connel, 2004; Mazer, 2012a, 2013a; Skinner, et al., 2008). Skinner and colleagues (2008) found that providing support to the students was the most beneficial act that a teacher could do to increase motivation and engagement. Umbach and Wawrzynski (2005) looked specifically at college students and found that challenging students through higher cognitive activities was an important aspect to creating an environment where students were engaged with course material. These challenges led students to be more involved in collaborative and active learning and students were more likely to interact with their faculty.

Faculty members have the opportunity to create an environment and culture that fosters learning by setting high standards, using active and collaborative assignments, interacting with their students, and providing support (Umbach \& Wawrzynski, 2005). Research on engagement needs to further identify and understand the role of educators and students in creating these results and how they may vary over time (Fredricks, Blumenfeld, \& Paris, 2004; Krause \& Coates, 2008; Linville, 2014, Mazer, 2013a). Servant teachers, with the focus on student development and success should positively impact student engagement; thus the following research question is offered:

RQ3: Are servant teaching and student engagement correlated?

\section{Methodology}

\section{Data Collection Procedures and Participants}

Students at a large Mid-Atlantic University in their introductory communication course were recruited using a cloud-based participant management program called SONA Systems. Participation in research studies is a required component of the course. Students create a SONA System log-in and select studies to complete on their own. Once they decided to participate in the current study they were provided with an informed consent form. After giving consent, they were taken to an online version of the instrument. The data collection began a few weeks into the semester and concluded around midterm to ensure student familiarity with course and instructor.

Students in the introductory communication course are primarily first year students with some second year and transfer students. The final results of the survey included 434 participants from a number of different sections of the course. The sample was heavily female (355 females, 76 males, 3 did not answer), mostly freshman (355 freshmen, 20 sophomore, 35 juniors, 22 seniors), and mostly white (351 white), The survey instructions asked students to think about their first class of the week in an attempt to capture a broad range of disciplines, instructors, and courses in the sample. The responses indicated a wide range of courses, whose professors were distributed between male and female and a variety of races.

\section{Instrumentation}

Journal of the Scholarship of Teaching and Learning, Vol. 15, No. 6, December 2015. Josotl.Indiana.edu 
Servant Leadership was operationalized using a modified version of the seven factor servant leadership scale created by Liden, Wayne, Zhao, and Henderson (2008). The seven factors are: conceptual skills, empowerment, helping subordinates grow and succeed, putting subordinates first, behaving ethically, emotional healing, and creating value for the community. The original version of this instrument asks respondents to select a leader and asks questions such as "He/She emphasizes the importance of giving back to the community" (Liden, et al., 2008). To modify this instrument for use in instructor-student context the He/She was replaced with "My Teacher." Some sample questions include the following: "My teacher cares about others' well-being," "My Teacher takes time to talk to others on a personal level," and "My teacher can solve academic problems with new or creative ideas." The questions were scored on a 5 point Likert scale with answers ranging from 1-never to 5-very often. The complete measure (Appendix A) contained 27 questions which captured all seven elements of servant leadership.

The measurement literature on servant leadership is mixed as related to its dimensionality. Consensus seems to be building that the best way to analyze servant leadership is as a unidimensional construct composed of the seven elements noted above (Hunter et al., 2013). In this study we use servant leadership as a proxy for servant teaching analyzing it both as a unidimensional construct (overall servant leadership) and by breaking out the seven elements to evaluate which element has the highest explanatory power. To arrive at the overall servant teaching score the items are summed and averaged. Scoring is the same for each of the seven subscales as the items corresponding to a particular element are summed and averaged.

The overall servant leadership reliability was strong in this study $(\alpha=.96, \mathrm{M}=97.037, S D$ $=18.56)$. Most of the subscales performed well with only ethics $(\alpha=.73)$ and empowering $(\alpha=.75)$ falling under .80 (all reliabilities and descriptive statistics for the scales can be seen in Table 1). The strength of the overall measure is consistent with the idea that servant leadership may indeed be a unidimensional construct (Hunter et. al, 2013).

Table 1. Reliability and descriptive statistics for scales in analysis

\begin{tabular}{llll} 
& $\alpha$ & $M$ & $S D$ \\
\hline Servant Leadership & 0.96 & 97.37 & 18.60 \\
Conceptual Skills & 0.86 & 15.04 & 3.13 \\
Empowering & 0.75 & 14.61 & 2.75 \\
Subordinates Grow & 0.87 & 14.88 & 3.18 \\
Subordinates First & 0.87 & 14.43 & 3.22 \\
Emotional Healing & 0.82 & 13.88 & 3.29 \\
Creating Value & 0.90 & 12.90 & 3.70 \\
Behaving Ethically & 0.73 & 11.62 & 2.16 \\
Motivation & 0.88 & 16.86 & 6.83 \\
Learning Indicators & 0.90 & 25.14 & 5.48 \\
Affective Learning & 0.75 & 51.23 & 11.22 \\
Student Engagement & 0.90 & 49.91 & 9.03 \\
\hline
\end{tabular}

Student Learning was measured using both affective and cognitive operationalizations. To measure student affective learning the revised affective learning scale was used. This scale asks 
students to report on their attitudes about the instructor, course content, and course overall (Mottet \& Richmond, 1998). Weber, Martin, and Patterson (2001) provided evidence that some of the subscales were redundant. As a result, this study used the four subscales: course content, appreciation, application, and instructor (Appendix A).

Each of the subscales consists of four items representing student attitudes about the course, application of course content, the instructor, and likelihood of taking another class with the teacher. The scale uses a semantic differential scale (good/bad, worthless/valuable, fair/unfair, positive/negative, likey/unlikely, impossible/possible, probable/improbable, and would/would not) (Frymier \& Houser, 2000; Mottet \& Richmond, 1998; Weber, Martin, \& Patterson, 2001). Each set of bipolar adjectives follows from a statement which represents the specific subscale. For example, "My attitude about the content of this course:" and "In real life situations, my likelihood of actually recalling and using some of the information from this class:" represent the course content and application dimensions (Mottet \& Richmond, 1998). The items for the overall scale are summed and averaged to arrive at the overall score for affective learning. For this study, affective learning is treated as a unidimensional construct as the concern here is overall affect, not a particular type of affect. This is consistent with research on affective learning (Mottet \& Richmond, 1998; Weber, Martin, \& Patterson, 2001). Reliability in this study for overall affective learning was acceptable $(\alpha=.75, M=51.23, S D=11.22)$ (Frymier \& Houser, 2000; Noland \& Richards, 2014; Weber, Martin, \& Patterson, 2001).

Affective learning is a measure of attitudinal learning, but it is important to measure cognitive learning. Cognitive learning is operationalized using the unidimensional revised learning indicators scale (Frymier \& Houser, 1999). Instead of using exams or grades, the learning indicators scale asked students about behaviors that indicate they are learning in the class as a proxy for cognitive learning. These behaviors include: "I see connections between the course content and my career goals; I review the course content; I explain course content to others; and I compare the information from this class with other things that I have learned.” The revised learning indicators scale asked students how often they engaged in the behaviors and was scored using a Likert scale with choices ranging from 1-never to 5-very often. To calculate the learning indicators scale the seven items were summed and averaged. Reliability in this study was consistent with previous research $(\alpha=.90, M=25.14, S D=5.48)$ (Frymier \& Houser, 1999; Mazer, 2013b; Wanzer, Frymier, \& Irwin, 2010).

Student Motivation was operationalized using Richmond's (1990) student state motivation scale. This unidimensional scale consisted of five items all responding to the question "How do you feel about studying for this class?” (Richmond, 1990). This orientation allows for the context to be a specific course reflecting student state motivation instead of focusing on the more stable trait motivation. Similar to the affective learning measure, the state motivation scale used a semantic differential scale with five bi-polar adjectives (motivated/unmotivated, excited/bored, uninterested/interested, involved/uninvolved, dreading it/looking forward to it). To calculate the student motivation score the items are summed and averaged. Coefficient alpha for this measure was consistent with previous research and indicated strong reliability ( $\alpha=.89, M=16.12, S D=6.73$ ) (Frymier \& Houser, 2000; Myers \& Zhong, 2004; Noland \& Richards, 2014; Richmond, 1990).

Student Engagement was operationalized using Mazer's (2012b) student interest and engagement scale. This unidimensional scale consists of thirteen items in which students respond about how frequently (1-never to 5-very often) they have engaged in certain activities in or outside of class. Sample items include, "Attended Class," "Thought about how the course material related to my life," and "Talked about the course material with others outside of class." To calculate the 
student engagement score, the items are summed and averaged. Previous reliabilities for student engagement have been strong (Linville, 2014; Mazer, 2013a) and coefficient alpha was consistent with past research $(\alpha=.90, M=49.91, S D=9.03)$.

\section{Results}

To test the research questions, servant teaching, the independent variable, was tested both as an aggregate and using the seven subscales. Given the exploratory nature of this study, the student outcome variables were first regressed, using multiple regression, on servant leadership as an aggregate after controlling for student academic year, sex, student attendance, and teacher sex. Subsequently, using multiple regression, they were regressed with the set of servant leadership subscales as the independent variables to determine which elements of servant leadership account for the most variance in student outcomes, again controlling for the same variables. Testing as an aggregate and in subscales is consistent with research on servant leadership in which researchers use both unidimensional and multidimensional analyses (Hunter et al., 2013; van Dierendock, 2011). Table 2 contains the intercorrelations for the predictor variables and outcome variables. Regression allowed for an analysis of the data at both aggregate and subscale levels and allowed for testing of prediction instead of mere association after controlling for key control variables. Appendix B contains the regression equations for the models used to test each of the research questions.

Table 2. Intercorrelations for variables and predictor variables

\begin{tabular}{|c|c|c|c|c|c|c|c|c|c|c|c|c|}
\hline Scale & 1 & 2 & 3 & 4 & 5 & 6 & 7 & 8 & 9 & 10 & 11 & 12 \\
\hline 1. Servant & -- & & & & & & & & & & & \\
\hline 2. Learn Ind. & $.394 *$ & -- & & & & & & & & & & \\
\hline 3. Motivation & $-.374^{*}$ & $-.494 *$ & -- & & & & & & & & & \\
\hline 4. Affect & $-.462 *$ & $-.456 *$ & $.657^{*}$ & -- & & & & & & & & \\
\hline 5. Engage & $.530^{*}$ & $.638^{*}$ & $-.542 *$ & $-.502 *$ & -- & & & & & & & \\
\hline 6. Emotional & $.901^{*}$ & $.351^{*}$ & $-.356^{*}$ & $-.427 *$ & $.476^{*}$ & -- & & & & & & \\
\hline 7. Value & $.789 *$ & $.310^{*}$ & $-.303^{*}$ & $-.300 *$ & $.384 *$ & $.716^{*}$ & -- & & & & & \\
\hline 8. Conceptual & $.896^{*}$ & $.396 *$ & $-.359 *$ & $-.452 *$ & $.514^{*}$ & $.741^{*}$ & $.607^{*}$ & -- & & & & \\
\hline 9. Empower & $.832 *$ & $.299 *$ & $-.286^{*}$ & $-.391 *$ & $.445^{*}$ & $.665^{*}$ & $.548^{*}$ & $.758 *$ & -- & & & \\
\hline 10. Grow & $.925^{*}$ & $.352 *$ & $-.354^{*}$ & $-.457 *$ & $.499 *$ & $.820^{*}$ & $.641^{*}$ & $.829 *$ & $.739 *$ & -- & & \\
\hline 11. Sub. First & $.918 *$ & $.336 *$ & $-.325 *$ & $-.435 *$ & $.468 *$ & $.825 *$ & $.663^{*}$ & $.794 *$ & $.710 *$ & $.866^{*}$ & -- & \\
\hline 12. Ethics & $.780 *$ & $.343^{*}$ & $-.262 *$ & $-.335 *$ & $.429 *$ & $.635 *$ & $.469 *$ & $.715^{*}$ & $.682 *$ & $.697 *$ & $.672 *$ & -- \\
\hline
\end{tabular}

Research question one asked if servant teaching and student motivation were related. Aggregate servant leadership was entered into the regression with the control variables and motivation. The model was significant with $15.6 \%$ explanatory power with student motivation $\left(R^{2}\right.$ $=.156, F(5,428=15.80, p<.01)$. Servant teaching emerged as a significant, but negative, predictor in the model after controlling for student sex, attendance, academic year, and teacher sex $(\beta=-.360, p<.01)$. To further discern the impact of each of the elements of servant teaching on student motivation a multiple regression, see Table 3, was performed with the seven elements of servant teaching and the control variables as the independent variables and student motivation as the outcome variable. The results of the multiple regression were significant with $16.8 \%$ of the 
variance being explained $\left(R^{2}=.168, F(11,422=7.74, p<.01)\right.$. The analysis of individual independent variables (the seven elements) is illustrative. Only conceptual skills ( $\beta=-.362, p=$ .023) contributed to significant variance above and beyond the control variables and other elements of servant teaching. The other individual predictors did not account for significant explanatory power with regard to student motivation.

Table 3. Multiple regression analysis for predictors of student motivation

\begin{tabular}{llllll}
\hline Predictor & $\mathrm{B}$ & $\mathrm{SE}$ & $\beta$ & $95 \% \mathrm{CI}$ & $p$ \\
\hline Academic Year & -0.02 & 0.01 & -0.10 & $(-0.039,0)$ & 0.06 \\
Student Sex & 0.01 & 0.01 & 0.06 & $(-0.005,0.026)$ & 0.20 \\
Student Attend & -0.07 & 0.07 & -0.04 & $(-0.204,0.068)$ & 0.33 \\
Teacher Sex & -0.01 & 0.01 & -0.06 & $(-0.022,0.005)$ & 0.23 \\
Emotional healing & -0.25 & 0.15 & -0.15 & $(-0.545,0.054)$ & 0.11 \\
Create Value & -0.10 & 0.10 & -0.07 & $(-0.29,0.091)$ & 0.30 \\
Conceptual & -0.36 & 0.16 & -0.21 & $(-0.673,-0.051)$ & $0.02 *$ \\
Empowering & 0.03 & 0.15 & 0.02 & $(-0.258,0.324)$ & 0.83 \\
Helping Grow & -0.18 & 0.19 & -0.11 & $(-0.545,0.18)$ & 0.32 \\
Subordinates First & 0.13 & 0.17 & 0.08 & $(-0.208,0.464)$ & 0.46 \\
Behaving Ethically & 0.07 & 0.13 & 0.04 & $(-0.183,0.329)$ & 0.58 \\
\hline
\end{tabular}

${ }^{*} p<.05$

Research question two asked if servant teaching and student learning were related. First, aggregate servant leadership was entered into a regression model with the control variables and affective learning. The same process was used to analyze student indicators of learning. Then the same sequence was followed using multiple regression with the seven elements as the independent variables along with control variables and affective learning and learning indicators as dependent variables respectively.

Research question two examining servant teaching at the aggregate level found evidence for a relationship with both affective learning and learning indicators. The model with aggregate servant teaching and the control variables exhibited $23.6 \%$ of the variance in affective learning $\left(R^{2}=.236, F(5,428)=26.40, p<.01\right)$. Again, there was a negative correlation $(r=-.46, p<.01)$. The model also exhibited $18.9 \%$ explanatory power of learning indicators $\left(R^{2}=.189, F(5,428)=\right.$ 19.91, $p<.01$ ). In contrast to affective learning and motivation, servant leadership, and learning indicators were positively correlated $(r=.39, p<.01)$. A multiple regression was conducted, see Tables 4 and 5, using the seven elements as independent variables along with the control variables, to determine the relative amount of variance that each of the elements of servant teaching contributed to student affective learning and indicators of learning.

The results of the multiple regression with the seven elements of servant leadership were significant for both affective learning and learning indicators. The model with the seven elements and control variables accounted for $25.8 \%$ of the variance in affective learning $\left(R^{2}=.258, F(11\right.$, $422)=13.33, p<.01)$. Further examination of the seven elements of servant teaching again yielded conceptual skills ( $\beta=-.217, p=.01$ ) as the only significant, and negative, predictor. The other six elements of servant teaching did not individually add significant explanatory power to affective learning. Servant teaching also predicted student indicators of learning by explaining $21 \%$ of the variance $\left(R^{2}=.210, F(11,422)=10.21, p<.01\right)$. Again only, though this time positively, conceptual skills $(\beta=.293, p=.001)$, of the seven elements of servant teaching exhibited significant explanatory power. 
Noland and Richards

Table 4. Multiple regression analysis for predictors of affective learning

\begin{tabular}{llllll}
\hline Predictor & $\mathrm{B}$ & $\mathrm{SE}$ & $\beta$ & $95 \% \mathrm{CI}$ & $p$ \\
\hline Academic Year & -0.01 & 0.01 & -0.13 & $(-0.023,-0.004)$ & $0.01^{*}$ \\
Student Sex & 0.01 & 0.00 & 0.11 & $(0.002,0.017)$ & $0.02^{*}$ \\
Student Attend & -0.01 & 0.03 & -0.02 & $(-0.078,0.054)$ & 0.72 \\
Teacher Sex & 0.00 & 0.00 & -0.05 & $(-0.01,0.003)$ & 0.26 \\
Emotional healing & -0.12 & 0.07 & -0.14 & $(-0.262,0.028)$ & 0.12 \\
Create Value & 0.06 & 0.05 & 0.08 & $(-0.033,0.152)$ & 0.21 \\
Conceptual & -0.19 & 0.08 & -0.22 & $(-0.345,-0.043)$ & $0.01^{*}$ \\
Empowering & -0.06 & 0.07 & -0.06 & $(-0.205,0.077)$ & 0.37 \\
Helping Grow & -0.13 & 0.09 & -0.15 & $(-0.309,0.043)$ & 0.14 \\
Subordinates First & -0.06 & 0.08 & -0.07 & $(-0.22,0.105)$ & 0.49 \\
Behaving Ethically & 0.07 & 0.06 & 0.08 & $(-0.051,0.197)$ & 0.25 \\
\hline
\end{tabular}

${ }^{*} p<.05$

Table 5. Multiple regression analysis summary for predictors of student learning indicators

\begin{tabular}{llllll}
\hline Predictor & $\mathrm{B}$ & $\mathrm{SE}$ & $\beta$ & $95 \% \mathrm{CI}$ & $p$ \\
\hline Academic Year & 0.00 & 0.01 & 0.01 & $(-0.01,0.013)$ & 0.79 \\
Student Sex & 0.00 & 0.00 & -0.01 & $(-0.009,0.008)$ & 0.91 \\
Student Attend & 0.15 & 0.04 & 0.18 & $(0.078,0.23)$ & $0.00^{*}$ \\
Teacher Sex & 0.01 & 0.00 & 0.07 & $(-0.002,0.013)$ & 0.16 \\
Emotional healing & 0.07 & 0.09 & 0.08 & $(-0.093,0.241)$ & 0.38 \\
Create Value & 0.06 & 0.05 & 0.08 & $(-0.043,0.17)$ & 0.24 \\
Conceptual & 0.29 & 0.09 & 0.29 & $(0.119,0.466)$ & $0.00^{*}$ \\
Empowering & -0.09 & 0.08 & -0.08 & $(-0.249,0.076)$ & 0.30 \\
Helping Grow & 0.00 & 0.10 & 0.00 & $(-0.199,0.206)$ & 0.97 \\
Subordinates First & -0.07 & 0.10 & -0.08 & $(-0.261,0.114)$ & 0.44 \\
Behaving Ethically & 0.13 & 0.07 & 0.12 & $(-0.009,0.276)$ & 0.07 \\
\hline
\end{tabular}

${ }^{*} p<.05$

Research question three asked if servant teaching and student engagement were related. Similar to learning indicators the relationship between servant teaching and student engagement was positive ( $r=.530, p<.01$ ). The model with aggregate servant leadership and the control variables as independent variables accounted for significant explanatory power, $31.3 \%$, of student engagement $\left(R^{2}=.313, F(5,428)=39.01, p<.01\right)$. Servant leadership emerged as a significant predictor above and beyond the control variables $(\beta=.503, p<.001)$. A multiple regression was conducted, see Table 6, to determine which individual elements of servant leadership exhibited significant explanatory power above and beyond the control variables. The resulting model was significant as the multi-dimensional measures of servant leadership demonstrated 32.5\% explanatory power on student engagement. The test of individual elements again yielded conceptual skills as the only significant predictor after controlling for the control variables and other elements of servant leadership $(\beta=.245, p<.01)$.

Table 6. Multiple regression analysis summary for predictors of student engagement

$\begin{array}{llllll}\text { Predictor } & \text { B } & \text { SE } & \beta & 95 \% \text { CI } & p\end{array}$


Noland and Richards

\begin{tabular}{llllll}
\hline Academic Year & 0.01 & 0.01 & 0.07 & $(-0.002,0.016)$ & 0.12 \\
Student Sex & 0.00 & 0.00 & 0.04 & $(-0.004,0.01)$ & 0.41 \\
Student Attend & 0.11 & 0.03 & 0.14 & $(0.045,0.17)$ & $0.00^{*}$ \\
Teacher Sex & 0.00 & 0.00 & 0.03 & $(-0.004,0.009)$ & 0.46 \\
Emotional healing & 0.10 & 0.07 & 0.11 & $(-0.041,0.234)$ & 0.17 \\
Create Value & 0.02 & 0.04 & 0.03 & $(-0.066,0.108)$ & 0.64 \\
Conceptual & 0.22 & 0.07 & 0.25 & $(0.075,0.36)$ & $0.00^{*}$ \\
Empowering & 0.04 & 0.07 & 0.04 & $(-0.09,0.176)$ & 0.53 \\
Helping Grow & 0.11 & 0.09 & 0.13 & $(-0.053,0.279)$ & 0.18 \\
Subordinates First & -0.04 & 0.08 & -0.04 & $(-0.191,0.117)$ & 0.64 \\
Behaving Ethically & 0.05 & 0.06 & 0.05 & $(-0.066,0.169)$ & 0.39 \\
\hline
\end{tabular}

${ }^{*} p<.05$

\section{Discussion}

Three important implications can be drawn from the results of this study: a) servant teaching is well positioned to impact student indicators of learning and engagement $b$ ) theoretical development in this context is warranted, and c) measurement, particularly related to the dimensionality of the servant leadership construct and scale require further study. The broad purpose of this study was to discern if servant leadership is an appropriate leadership style for instruction. Though this is but one study, the evidence provided here supports elements of servant leadership as viable. Luechauer and Shulman (2002) along with Pounder (2008) have called on scholars to apply different leadership approaches to classroom instruction. The servant approach to leadership capitalizes on the altruistic nature of teaching as "student-centered," by focusing on follower development. This study provides a step toward concretizing servant teaching which will provide teachers with specific approaches and behaviors to positively impact student outcomes. This praxis approach can extend the theoretical and empirical body of literature while providing teachers with clear prescriptions of how to impact student outcomes.

The primary goal of teaching is student learning and development. Servant teachers are those who put this goal into action by focusing on follower development, putting their followers first, providing opportunities for followers to grow and succeed, and empowering students (Barbuto \& Wheeler, 2006; Greenleaf, 1977; Hunter et al., 2013). The findings related to student motivation and affective learning were surprising. The concepts of servant leadership may facilitate cognitive learning and student engagement with the course, but have negative impacts on affect and motivation because of the very nature of servant leadership as a construct. That is, servant teaching may focus more on student needs (e.g. learning and engagement) without directly influencing the moderators of student learning (e.g. motivation and affect). Many dimensions of teacher charisma are demonstrated to influence student motivation such as immediacy and teacher transformational leadership (Frymier, 1993; Noland \& Richards, 2014). As these teacher behaviors are more about teacher dynamism and charisma they are likely to influence student attitudes toward the course and the teacher. Servant teaching, on the other hand, is about the teacher's out of class behaviors (community engagement), teacher selflessness (helping students learn and grow, putting students first), and organizational skills (conceptual skills). These behaviors are more consistent with learning indicators and student engagement instead of affect and motivation. Therefore, servant teaching may both directly and indirectly impact student learning. Additional research should seek to explore how elements of servant teaching can be combined with immediacy, which 
is demonstrated to improve motivation, to help promote both affective and cognitive dimensions of learning. That is, teachers may want to engage in creative borrowing from multiple pedagogical approaches to improve student outcomes.

Servant teaching is well positioned to provide teachers with a set of tools to improve student indicators of learning and engagement. Student engagement is an important variable as both an ends and a potential mediator to other desired student outcomes. More research is needed to investigate the relationship between servant teaching and student engagement and the potential implications of this relationship. A structural equation modeling approach may be helpful to add servant teaching to existing theoretical models containing student engagement to see how they may compliment or magnify effects.

Finally, the lack of differentiation among the individual predictors was surprising given the strength of the aggregate relationship between servant teaching and student outcomes. This calls into question the dimensionality of a servant approach to teaching. It is clear after examining the intercorrelations among the seven elements of servant teaching that the multicollinearity between the predictors attenuated the individual predictive utility of the seven elements. With so much shared variance between the predictors, they are accounting for the same variance in the outcome variables and thus did not emerge as significant individually. However, the aggregate servant leadership models indicated significant variance accounted for suggesting that servant leadership may be unidimensional. Some researchers (Hunter et al., 2013) have argued for a unidimensional approach to servant leadership. The lack of unique variance explained in the beta weight analysis and the high level of reliability for the aggregate scale compared to the subscales, seems to, in this study, support unidimensionality. Organizational leadership theorists have called for further construct and scale development (Hunter et al., 2013; van Dierendock, 2011). Theoretical development with regard to servant teaching should continue to hone the bounds and differentiation between servant teaching and other pedagogical approaches.

\section{Limitations and Future Research}

Despite providing evidence for servant teaching's impact on student outcomes this study was not without limitations. The sample was primarily comprised of female students in their first year of college who are mostly white; however, a wide range of professors, both racially and in terms of academic discipline, were represented. Sampling young students may be problematic as they are still learning about different instructional styles and college-level instruction in general. Thus, they may not recognize some of the behaviors solicited in the instrument. Umbach and Wawrzynski (2005) found in a national sample $(\mathrm{N}=42,259)$ comparing seniors to first-year students and controlling for institutional factors the impact of environmental support was only significant for seniors. This finding lends support to sampling students who have spent more time on campus as they may be more aware of the influence of their instructors. Future studies should sample students in different years in order to compare them to one another.

Future research should investigate the psychometrics of the servant leadership scale. This scale, highly reliable in previous research (Liden et al., 2008) was adapted to fit the classroom from more traditional business environments and seemed to hold up well in this context. Scale assessment and development will be a crucial element to bolstering servant teaching research. New studies should work to develop scales specific to the classroom setting that are consistent with servant leadership's theoretical underpinnings. 
Additionally, disagreement exists among scholars of servant leadership about the nature of this construct. Some scholars argue servant leadership has nine dimensions, some seven, and some argue that it is unidmensional (Liden, 2008; Hunter et al., 2013; van Dierendonck, 2011). The lack of clarity makes inferences about servant teaching somewhat tenuous as they are based on aggregate and subscale data. To resolve this potential limitation this project tested servant leadership's predictive relationship with student outcomes at both the aggregate and subscale level. The resulting analysis was, perhaps, one of the most interesting findings of this research. In all three subscale tests of servant leadership on motivation, affective learning, and learning indicators, only conceptual skills accounted for significant variance after controlling for other variables in the model. Future research should attempt to better understand the factor structure of servant teaching as a construct and, if appropriate, the relative impact of each of the elements of servant teaching on student outcomes. A more comprehensive understanding of the nature of servant teaching will require statistical methods like those used by Liden et. al (2008) applied to servant teaching instruments specifically designed for this context. Additionally, testing competing models about the dimensionality of servant leadership will allow for more precise inferences to be drawn from the measure.

Finally, this study only investigated the relationship between servant teaching and student motivation, learning, and engagement. Future research should continue to explore this relationship while extending the analysis of student outcomes to include concepts such as empowerment, learning orientation, affinity, and others. Additionally, to bolster the authenticity of servant teaching research, mediator and moderators should be considered. For example, immediacy is often used as a predictor variable in instructional research, but it is unknown if immediacy mediates the relationship between teacher leadership style and student outcomes. Other mediators and moderators should be explored and modeled to achieve a more precise and robust representation of servant teaching's impact on student outcomes.

\section{Conclusion}

This research sought to understand if servant teaching correlated with student outcomes such as motivation, learning, and engagement. The empirical results of this study provide evidence that a relationship exists between servant teaching and student outcomes. Particularly, servant teaching was positively correlated with student indicators of learning and engagement. On the other hand, a negative association was found between servant teaching and student motivation and affect. The combination of these results is illustrative. Servant teaching is focused on student development and putting the needs of students ahead of that of the teacher. Given how these concepts are operationalized it is not surprising that the lack of state motivation in relation to a particular course or affect would be positive. Simply stated, servant teaching does not focus on attitudinal learning as operationalized on the affective learning scale, instead focusing more on outcomes than on attitudes. In a more robust analysis using structural equation modeling, it may be that the relationship between servant teaching and affect and motivation is mediated by another instructional communication variable (Mazer, 2013a). More study of these models is necessary to understand how servant teaching functions in conjunction with other instructor behaviors and student characteristics (Rodriguez, Plax, \& Kearney, 1996).

The implications of this study for teachers are specific and worth noting. In an environment with so many options and extensive research, teachers need specific recommendations for improving their behaviors and thus student outcomes. In this study evidence for the impact of 
overall servant orientation toward teaching was found. For teachers, this means empowering students, putting their needs first, being organized and clear with information (conceptual skills), all while working towards an approach of student development. All of these elements demonstrate a positive correlation to student learning indicators and engagement. To address student motivation and affective learning it may be necessary for teachers to also employ immediacy behaviors and elements of transformational leadership (Chesebro, 2003; Comadena, Hunt, \& Simonds, 2007; Noland \& Richards, 2014;).

Overall, this study answers the call for additional research into the teacher as leader (Luechauer \& Shulman, 2002; Pounder, 2008) and specifically for exploring servant leadership as a model for instruction (Bowman, 2005; Drury, 2005). The evidence provided here, contextualized by previous research, demonstrates a new area of research. Continued theoretical development and measurement work is needed on servant teaching, but this domain is rich for exploration and with implications for teachers in the classroom. Exploring the broader picture of how servant teaching fits within models consisting of other instructor behaviors and student outcomes is the logical next step.

This research was exploratory, but the research questions were supported providing evidence that servant teaching merits further investigation and is viable as an approach to instruction, though it may need to be added to existing pedagogical processes. Teaching is a relational process wherein the focus is student development and servant teaching is consistent with this philosophy. Paulo Freire (1990) in, We Make the Road by Walking: Conversations on Education and Social Change, argued "What the educator does in teaching is to make it possible for the students to become themselves" (Horton, Bell, Gaventa, \& Peters, 1990, pg. 181). Servant teaching is aimed at helping students develop into the best version of themselves by focusing on student needs above all else. 


\section{Servant Leadership}

\section{Appendix A: Instrument}

\section{1-never 2-rarely 3-occasionally 4-often 5-very often}

1. Other students would seek help from my teacher if they had a personal problem.

2. My teacher emphasizes the importance of giving back to the community.

3. My teacher can tell if something related to the class is going wrong.

4. My teacher gives students the responsibility to make important decisions about their own academic work.

5. My teacher makes students' development a priority.

6. My teacher cares more about students' success than his/her own.

7. My teacher holds high ethical standards.

8. My teacher cares about students' personal well-being.

9. My teacher is always interested in helping people in the community.

10. My teacher is able to think through complex problems.

11. My teacher encourages students to handle important academic decisions on their own.

12. My teacher is interested in making sure students reach their academic goals.

13. My teacher puts students' best interests above his/her own.

14. My teacher is always honest.

15. My teacher takes time to talk to students on a personal level.

16. My teacher is involved in community activities.

17. My teacher has a thorough understanding of the class and its goals.

18. My teacher gives students the freedom to handle difficult situations in the way they feel is best.

19. My teacher provides students with academic experiences that enable them to develop new skills.

20. My teacher sacrifices his/her own interests to meet students' needs.

21. My teacher would not compromise ethical principles in order to meet success.

22. My teacher can recognize when students are feeling down without asking them.

23. My teacher encourages students to volunteer in the community.

24. My teacher can solve academic problems with new or creative ideas.

25. If students need to make important decisions, they do not need to consult the teacher.

26. My teacher wants to know about students' academic goals.

27. My teacher does what they can to make students' jobs easier.

\section{Questions by Subscale}

Emotional healing: 1, 8, 15, 22

Creating value for community: 2, 9, 16, 23

Conceptual skills: 3, 10, 17, 24

Empowering: 4, 11, 18, 25

Helping subordinates grow and succeed: 5, 12, 19, 26

Putting subordinates first: 6, 13, 20, 27

Ethics: 7, 14, 21, 28

\section{Affective Learning}

Journal of the Scholarship of Teaching and Learning, Vol. 15, No. 6, December 2015.

Josotl.Indiana.edu 
My attitude about the content of this course:

$\begin{array}{lllllllll}\text { 1. Good } & 7 & 6 & 5 & 4 & 3 & 2 & 1 & \text { Bad } \\ \text { 2. Worthless } & 7 & 6 & 5 & 4 & 3 & 2 & 1 & \text { Valuable } \\ \text { 3. Fair } & 7 & 6 & 5 & 4 & 3 & 2 & 1 & \text { Unfair } \\ \text { 4. Positive } & 7 & 6 & 5 & 4 & 3 & 2 & 1 & \text { Negative }\end{array}$

The likelihood of my developing an “appreciation” for the content/subject matter:

\begin{tabular}{|c|c|c|c|c|c|c|c|c|}
\hline 5. Likely & 7 & 6 & 5 & 4 & 3 & 2 & 1 & Unlikely \\
\hline 6. Impossible & 7 & 6 & 5 & 4 & 3 & 2 & 1 & Possible \\
\hline 7. Probable & 7 & 6 & 5 & 4 & 3 & 2 & 1 & Improbable \\
\hline 8. Would & 7 & 6 & 5 & 4 & 3 & 2 & 1 & Would Not \\
\hline
\end{tabular}

In "real life" situations, my likelihood of actually recalling and using some of the information from this class:

\begin{tabular}{|c|c|c|c|c|c|c|c|c|}
\hline 9. Likely & 7 & 6 & 5 & 4 & 3 & 2 & 1 & Unlikely \\
\hline 10. Impossible & 7 & 6 & 5 & 4 & 3 & 2 & 1 & Possible \\
\hline 11. Probable & 7 & 6 & 5 & 4 & 3 & 2 & 1 & Improbable \\
\hline 12. Would & 7 & 6 & 5 & 4 & 3 & 2 & 1 & Would Not \\
\hline
\end{tabular}

My attitude about the instructor of this course:

$\begin{array}{lllllllll}\text { 13. Good } & 7 & 6 & 5 & 4 & 3 & 2 & 1 & \text { Bad } \\ \text { 14. Worthless 7 } & 6 & 5 & 4 & 3 & 2 & 1 & & \text { Valuable } \\ \text { 15. Fair } & 7 & 6 & 5 & 4 & 3 & 2 & 1 & \text { Unfair } \\ \text { 16. Positive } & 7 & 6 & 5 & 4 & 3 & 2 & 1 & \text { Negative }\end{array}$

\section{Learning Indicators}

1-never 2-rarely 3-occasionally 4-often 5-very often

1.

2.

3.

4.

5.

6.

7.
I like to talk about what I'm doing in this class with friends and family. I explain course content to other students.

I think about course content outside the class.

I see connections between the course content and my career goals.

I review the course content.

I compare the information from this class with other things that I have learned.

I feel I have learned a lot in this class.

\section{Motivation}

How do you feel about studying for this class?

\begin{tabular}{|c|c|c|c|c|c|c|c|c|}
\hline 1. Motivated & 7 & 6 & 5 & 4 & 3 & 2 & 1 & Unmotivated \\
\hline 2. Excited & 7 & 6 & 5 & 4 & 3 & 2 & 1 & Bored \\
\hline 3. Uninterested & 7 & 6 & 5 & 4 & 3 & 2 & 1 & Interested \\
\hline 4. Involved & 7 & 6 & 5 & 4 & 3 & 2 & 1 & Uninvolved \\
\hline 5. Dreading It & 7 & 6 & 5 & 4 & 3 & 2 & 1 & Looking Forward to it \\
\hline
\end{tabular}

\section{Student Engagement}

\section{1-never 2-rarely 3-occasionally 4-often 5-very often}

1. Listened attentively to the instructor during class.

2. Gave your teacher your full attention during class.

3. Listened attentively to your classmates' contributions during class discussions.

4. Attended class. 
Noland and Richards

5. Participated during class discussions by sharing your thoughts \& opinions.

6. Orally (verbally) participated during class discussions.

7. Thought about how you can utilize the course material in your everyday life.

8. Thought about how the course material related to your life.

9. Thought about how the course material will benefit you in your future career.

10. Reviewed your notes outside of class.

11. Studied for a test or quiz.

12. Talked about the course material with others outside of class.

13. Took it upon yourself to read additional material in the course topic area.

\section{Appendix B: Regression Models}

Journal of the Scholarship of Teaching and Learning, Vol. 15, No. 6, December 2015. Josotl.Indiana.edu 
Noland and Richards

Variables:

Student motivation = MOT; Student affective learning = AFF; Student learning indicators = SLI; Student engagement $=$ ENG; Emotional healing $=\mathrm{EMH}$; Creating value $=$ VAL; Conceptual skills = CON; Empowering students = EMP; Grow and succeed = GROW; Putting student first = PUT; Behaving ethically = ETH; Overall servant teaching = OST; Student Sex = SSEX; Academic Year

= YEAR; Student Attendance $=$ ATT; and Teacher Sex $=$ TSEX.

\section{RQ1: Are servant teaching and student motivation correlated?}

Model 1:

$M O T=\beta_{0}+\beta_{1} A T T+\beta_{2} S S E X+\beta_{3} Y E A R+\beta_{4} T S E X+\beta_{5} O S T+\varepsilon$

Model 2:

$M O T=\beta_{0}+\beta_{1} A T T+\beta_{2} S S E X+\beta_{3} Y E A R+\beta_{4} T S E X+\beta_{5} E M H+\beta_{6} V A L+\beta_{7} C O N+\beta_{8} E M P+\beta_{9} G R O W$ $+\beta_{10} P U T+\beta_{11} E T H+\varepsilon$

\section{RQ2: Are servant teaching and student learning correlated?}

Affective Learning

Model 1:

$A F F=\beta_{0}+\beta_{1} A T T+\beta_{2} S S E X+\beta_{3} Y E A R+\beta_{4} T S E X+\beta_{5} O S T+\varepsilon$

Model 2:

$A F F=\beta_{0}+\beta_{1} A T T+\beta_{2} S S E X+\beta_{3} Y E A R+\beta_{4} T S E X+\beta_{5} E M H+\beta_{6} V A L+\beta_{7} C O N+\beta_{8} E M P+\beta_{9} G R O W+$ $\beta_{10} P U T+\beta_{11} E T H+\varepsilon$

Learning Indicators

Model 1:

$S L I=\beta_{0}+\beta_{1} A T T+\beta_{2} S S E X+\beta_{3} Y E A R+\beta_{4} T S E X+\beta_{5} O S T+\varepsilon$

Model 2:

$S L I=\beta_{0}+\beta_{1} A T T+\beta_{2} S S E X+\beta_{3} Y E A R+\beta_{4} T S E X+\beta_{5} E M H+\beta_{6} V A L+\beta_{7} C O N+\beta_{8} E M P+\beta_{9} G R O W+$ $\beta_{10} P U T+\beta_{11} E T H+\varepsilon$

\section{RQ3: Are servant teaching and student engagement correlated?}

Model 1:

$E N G=\beta_{0}+\beta_{1} A T T+\beta_{2} S S E X+\beta_{3} Y E A R+\beta_{4} T S E X+\beta_{5} O S T+\varepsilon$

Model 2:

$E N G=\beta_{0}+\beta_{1} A T T+\beta_{2} S S E X+\beta_{3} Y E A R+\beta_{4} T S E X+\beta_{5} E M H+\beta_{6} V A L+\beta_{7} C O N+\beta_{8} E M P+\beta_{9} G R O W+$ $\beta_{10} P U T+\beta_{11} E T H+\varepsilon$

\section{References}

Journal of the Scholarship of Teaching and Learning, Vol. 15, No. 6, December 2015.

Josotl.Indiana.edu 
Appleton, J. J., Christenson, S. L., Kim, D., \& Reschly, A. L. (2006). Measuring cognitive and psychological engagement: Validation of the student engagement instrument. Journal of School Psychology, 44(5), 427-445. doi:10.1016/j.jsp.2006.04.002

Barbuto Jr., J. E., \& Wheeler, D. W. (2006). Scale development and construct clarification of servant leadership. Group \& Organization Management, 31(3), 300-326. doi:10.1177/1059601106287091 Bloom, B.S. (1956). Taxonomy of Educational Objective, Handbook I: The Cognitive Domain. New York: David McKay.

Bolkan, S. \& Goodboy, A.K. (2010). Transformational leadership in the classroom: The development and validation of the student intellectual stimulation scale. Communication Reports, 23, 91-105. doi:10.1080/08934215.2010.511399

Bolkan, S., \& Goodboy, A. K. (2011). Behavioral Indicators of Transformational Leadership in the College Classroom. Qualitative Research Reports in Communication, 12(1), 10-18. doi:10.1080/17459435.2011.601520

Bolkan, S., Goodboy, A. K., \& Griffin, D. J. (2011). Teacher leadership and intellectual stimulation: Improving students' approaches to studying through intrinsic motivation. Communication Research Reports, 28(4), 337-346. doi. 10.1080/08824096.2011.615958

Bogler, R., Caspi, A., \& Roccas, S. (2013). Transformational and passive leadership: An initial investigation of university instructors as leaders in a virtual learning environment. Educational Management Administration and Leadership, 41(3), 372-392. doi. 10.1177/1741143212474805 Bowman, R. F. (2005). Teacher as Servant Leader. Clearing House, 78(6), 257-259.

Carini, R. M., Kuh, G. D., \& Klein, S. P. (2006). Student engagement and student learning: Testing the linkages. Research in Higher Education, 47(1), 1-32. doi:10.1007/s11162-005-8150-9

Chesebro, J.L.(2003). Effects of teacher clarity and nonverbal immediacy on student learning, receiver apprehension, and affect. Communication Education, 52, 135 - 148.

Chory, R. M., \& McCroskey, J. C. (1999). The relationship between teacher management communication style and affective learning. Communication Quarterly, 47,1-11.

Comadena, M. E., Hunt, S. K., \& Simonds, C. J. (2007). The effects of teacher clarity, nonverbal immediacy, and caring on student motivation, affective and cognitive learning. Communication Research Reports, 24(3), 241-248. doi:10.1080/08824090701446617

Drury, S. 2005. Teacher as Servant Leader: A faulty model for effectiveness with students. Paper presented at the Servant Leadership Research Roundtable, Regent University, Virginia Beach, VA.

Fredricks, J. A., Blumenfeld, P. C., \& Paris, A. H. (2004). School engagement: Potential of the concept, state of the evidence. Review of Educational Research,74(1), 59-109. doi:10.3102/00346543074001059

Frymier, A.B. (1993). The relationships among communication apprehension, immediacy and 
Noland and Richards

motivation to study. Communication Reports, 6, 8-18.

Frymier, A.B., \& Houser, M.L. (1999). The revised learning indicators scale. Communication Studies, 50, $1-12$.

Frymier, A.B., \& Houser, M.L. (2000). The teacher-student relationship as an interpersonal relationship. Communication Education, 49, 207 - 219.

Frymier, A.B. \& Shulman, G.M. (1995). What's in it for me? Communication Education, 44, 4050 .

Goodboy, A. K., \& Myers, S. A. (2008). The effect of teacher confirmation on student communication and learning outcomes. Communication Education, 57, 153-179. doi:10.1080/03634520701787777

Greenleaf, R. K. (1977). Servant leadership: A journey into the nature of legitimate power and greatness. (Kindle DX version), Retreived from Amazon.com

Greenleaf, R. K. (1998). The power of servant leadership. L.C. Spears (Ed.). Kindle DX version.

Greenleaf, R. K. (2003). Teacher as Servant. In B. Hamilton, J. Beggs, \& L.C. Spears (Eds.), The servantleader within: A transformative path (Location 1243-3970). Kindle DX version, Retreived from Amazon.com

Hays, J. (2008). Teacher as servant applications of Greenleaf's servant leadership in higher education. Journal Of Global Business Issues, 2(1), 113-134.

Horan, S. M., Chory, R. M., Carton, S. T., Miller, E., \& Raposo, P. J. (2013). Testing leader-member exchange theory as a lens to understand students' classroom justice perceptions and antisocial communication. Communication Quarterly, 61(5), 497-518. doi:10.1080/01463373.2013.799511

Horton, M., Bell, B., Gaventa, J., \& Peters, J. M. (1990). We make the road by walking : conversations on education and social change. Philadelphia : Temple University Press.

Hunter, E. M., Neubert, M. J., Perry, S. J., Witt, L. A., Penney, L. M., \& Weinberger, E. (2013) Servant leaders inspire servant followers: Antecedents and outcomes for employees and the organization. Leadership Quarterly, 24(2), 316-331.

Jaasma, M.A. \& Koper, R.J. (1999). The relationship of student-faculty out-of-class communication to instructor immediacy and trust and to student motivation. Communication Education, 48, 41-47.

Jimerson, S. R., Campos, E., \& Greif, J. L. (2003). Toward an understanding of definitions and measures of school engagement and related terms. The California School Psychologist, 8(1), 7-27. doi:10.1007/BF03340893

Kark, R., Shamir, B., \& Chen, G. (2003). The two faces of transformational leadership: 
empowerment and dependency. Journal of Applied Psychology, 88, 246-255. doi: 10.1037/00219010.88.2.246

Klem, A. M., \& Connell, J. P. (2004). Relationships matter: Linking teacher support to student engagement and achievement. Journal of School Health, 74(7), 262-273. doi:10.1111/j.17461561.2004.tb08283.x

Krause, K., \& Coates, H. (2008). Student's engagement in first-year university. Assessment \& Evaluation in Higher Education, 33(5), 493-505. doi:10.1080/02602930701698892

Linville, D. (2014). Student Interest and Engagement in the Classroom: Relationships with Student Personality and Developmental Variables. Southern Communication Journal, 79(3), 201-214. doi:10.1080/1041794X.2014.884156

Luechauer, D.L. \& Shulman, G.M. (2002). Creating empowered learners: A decade trying to practice what we teach. Organizational Development Journal, 20, 42-50.

Liden, R. C., Wayne, S. J., Zhao, H., \& Henderson, D. (2008). Servant leadership: Development of a multidimensional measure and multi-level assessment Elsevier Inc. doi:10.1016/j.leaqua.2008.01.006 Mazer, J. P. (2012a). Associations among teacher communication behaviors, student interest, and engagement: A validity test. Communication Education, 62, 8696. doi:10.1080/036345 23.2012.731513

Mazer, J. P. (2012b). Development and validation of the Student Interest and Engagement Scales. Communication Methods and Measures, 6, 99125. doi:10.1080/19312458.2012.679244

Mazer, J. P. (2013a). Student Emotional and Cognitive Interest as Mediators of Teacher Communication Behaviors and Student Engagement: An Examination of Direct and Interaction Effects. Communication Education, 62(3), 253-277. doi:10.1080/03634523.2013.777752

Mazer, J. P. (2013b). Validity of the Student Interest and Engagement Scales: Associations with Student Learning Outcomes. Communication Studies, 64(2), 125-140. doi:10.1080/10510974.2012.727943

Mottet, T.P., \& Richmond, V.P., (1998). Newer is not necessarily better: A reexamination of the affective learning measurement. Communication Research Reports, 15, 370-378.

Myers, S. A., Goodboy, A. K., \& Members of, COMM 600. (2014). College student learning, motivation, and satisfaction as a function of effective instructor communication behaviors. Southern Communication Journal, 79(1), 14-26. doi:10.1080/1041794X.2013.815266

Myers, S. A., \& Zhong, M. (2004). Perceived Chinese instructor use of affinity-seeking strategies and Chinese college student motivation. Journal of Intercultural Communication Research, 33, 119-130.

Noland, A. \& Richards, K. (2014). The relationship among transformational teaching and student motivation and learning. The Journal of Effective Teaching, 14(3), 5-20. 
Patterson, K. A. 2003. Servant leadership: A theoretical model. Doctoral dissertation, Regent University. ATT No.3082719.

Pounder, J.S. (2003). Employing transformational leadership to enhance the quality of management development instruction. Journal of Management Development, 22, 1-13.

Pounder, J. S. (2006). Transformational classroom leadership: The fourth wave of teacher leadership? Educational Management Administration \& Leadership, 34, 533-545.

Pounder, J.S. (2008). Transformational classroom leadership: A novel approach to evaluating classroom performance. Assessment \& Evaluation in Higher Education, 33, 233-243. doi: $10.1080 / 02602930701292621$

Pounder, J. S. (2009). Transformational classroom leadership: A basis for academic staff development. Journal of Management Development, 28(4), 317-325. doi: $10.1108 / 02621710910947353$

Reeve, J., Jang, H., Carrell, D., Jeon, S., \& Barch, J. (2004). Enhancing students’ engagement by increasing teachers' autonomy support. Motivation and Emotion, 28(2), 147-169. doi:10.1023/b:moem.0000032312.95499.6f

Richmond, V.P. (1990). Communication in the classroom: Power and motivation. Communication Education, 39, 181-195.

Richmond, V.P. \& McCroskey, J.C. (1992). Organizational communication for survival. Englewood Cliffs, NJ: Prentice Hall.

Rodriguez, J., Plax, T.G., \& Kearney, P. (1996). Clarifying the relationship between teacher nonverbal immediacy and student cognitive learning: Affective learning as the central causal mediator. Communication Education, 45, 293-305.

Sidelinger, R.J., \& McCroskey, J.C. (1997). Communication correlates of teacher clarity in the college classroom. Communication Research Reports, 14, 1-10.

Skinner, E., Furrer, C., Marchand, G., \& Kindermann, T. (2008). Engagement and disaffection in the classroom: Part of a larger motivational dynamic?. Journal Of Educational Psychology, 100(4), 765-781. doi:10.1037/a0012840

Sorensen, G. (1989). The relationships among teachers' self-disclosive statements, students' perceptions, and affective learning. Communication Education, 38, 259-276.

Smith, B. N., Montagno, R. V., \& Kuzmenko, T. N. (2004). Transformational and servant leadership: Content and contextual comparisons. Journal of Leadership and Organizational Studies, 10, 80-91.

Stone, A. G., Russell, R. F., \& Patterson, K. (2004). Transformational versus servant leadership: A difference in leader focus. Leadership and Organization Development Journal, 25(4), 349-361. 
Noland and Richards

Teven, J. J., \& McCroskey, J. C. (1997). The relationship of perceived teacher caring with student learning and teacher evaluation. Communication Education, 46, 1-9. doi:10.1080/03634529709379069

Umbach, P. D., \& Wawrzynski, M. R. (2005). Faculty do matter: The role of college faculty in student learning and engagement. Research in Higher Education, 46(2), 153-184. doi: 10.1007/s11162-004-1598-1

van Dierendonck, D., \& Nuijten, I. (2011). The servant leadership survey: Development and validation of a multidimensional measure. Journal of Business \& Psychology, 26(3), 249-267. doi:10.1007/s10869010-9194-1

Wanzer, M. B., Frymier, A. B., \& Irwin, J. (2010). An explanation of the relationship between instructor humor and student learning: Instructional humor processing theory. Communication Education, 59(1), 1-18. doi:10.1080/03634520903367238

Weber, K., Martin, M.M., \& Patterson, B.R. (2001). Teacher behavior, student interest and affective learning: Putting theory to practice. Journal of Applied Communication Research, 29, 71-90.

Zyngier, D. (2008). (Re)conceptualising student engagement: Doing education not doing time. Teaching and Teacher Education, 24(7), 1765-1776. doi:10.1016/j.tate.2007.09.004 